\title{
Differences in carbon isotope discrimination and whole-plant transpiration efficiency among nine Australian and Sahelian Acacia species
}

\author{
Nianguiri M. Konate ${ }^{1,2} \cdot$ Erwin $^{\text {Dreyer }^{1}} \cdot$ Daniel Epron $^{1}$
}

Received: 5 July 2016 / Accepted: 6 October 2016 / Published online: 31 October 2016

(C) INRA and Springer-Verlag France 2016

\begin{abstract}
- Key message We observed coordinated differences in water-use efficiency, ${ }^{13} \mathrm{C}$ isotope composition, and wholeplant transpiration efficiency among nine Acacia species, although the up scaling from leaf to whole-plant level resulted in different relationships in Sahelian and Australian species.

- Context The genus Acacia sensu lato contains a large variety of tropical to Mediterranean species adapted to habitats ranging from mesic to arid in Africa and Australia.

- Aims We checked whether transpiration efficiency differed among a range of nine Sahelian and Australian species and whether it was related to the degree of aridity of the original area or to their type of foliage (pinnate leaves or phyllodes).

- Methods Intrinsic water-use efficiency $\left(W_{\mathrm{I}}\right)$ was recorded from leaf gas exchange and whole-plant transpiration

Handling Editor: Andrew Merchant

Contribution of the co-authors NMK has performed the experimental work and has analyzed the data during his $\mathrm{PhD}$ under the supervision of DE and ED. DE and ED have designed the experiment and written the article.
\end{abstract}

\section{Daniel Epron}

daniel.epron@univ-lorraine.fr

Nianguiri M. Konate

niangsfall@yahoo.fr

Erwin Dreyer

erwin.dreyer@inra.fr

1 Inra, UMR 1137, Ecologie et Ecophysiologie Forestières, Université de Lorraine, 54280 Champenoux, France

2 Present address: Institut Supérieur de l'Enseignement Technologique, Département de production et de protection végétale, Unité de Recherche Ressources Génétiques et Environnement, Rosso, Mauritanie efficiency (TE) from biomass production and water consumption of potted seedlings. Both $W_{\mathrm{I}}$ and TE were compared to ${ }^{13} \mathrm{C}$ discrimination $\left(\Delta^{13} \mathrm{C}\right)$ computed from either bulk foliage or extracted cellulose.

- Results At leaf level, $\Delta^{13} \mathrm{C}$ matched closely $W_{\mathrm{I}}$ across species, while at the whole-plant level, the relationship between $\mathrm{TE}$ and either $\Delta^{13} \mathrm{C}$ or $W_{\mathrm{I}}$ differed between the Sahelian and the Australian species. Large interspecific differences were found but they were not related to the aridity of the origin nor to the type of foliage.

- Conclusion $\Delta^{13} \mathrm{C}$ captured well the variability of $W_{\mathrm{I}}$ among several Acacia species while species differences in carbon-use efficiency (the fraction of carbon assimilated recovered in plant biomass) or the relative nocturnal transpiration may disrupt the relationship between TE and $\Delta^{13} \mathrm{C}$.

Keywords ${ }^{13} \mathrm{C} \cdot$ Carbon isotopes · Water-use efficiency Photosynthesis $\cdot$ Stomatal conductance $\cdot$ Transpiration

\section{Introduction}

A large transpiration efficiency (TE), defined as the cumulated amount of biomass produced relative to the cumulated amount of water used by transpiration, is often seen as a key strategy for plants living in areas where water availability may be limiting (Bacon 2004). A large TE should help plants to reduce their water consumption, thus increasing the time during which soil water can be used in absence of competition for water among co-occurring plants. For this reason, perennial plants such as trees with high TE are potentially able to perform better in water-limited environments than plants exhibiting low TE (Sun et al. 1996).

At leaf level, intrinsic water-use efficiency $\left(W_{\mathrm{I}}\right)$ is defined as the ratio of net $\mathrm{CO}_{2}$ assimilation through photosynthesis 
and stomatal conductance to water vapor (Bacon 2004). $W_{\mathrm{I}}$ is a complex trait and its variation may be related to variation in photosynthetic capacity and thus leaf nitrogen content and specific leaf area (Reich et al. 1998; Niinemets 1999; Takashima et al. 2004), and/or variation in stomatal conductance, under the influence of stomata morphology and anatomy (Franks and Farquhar 2007). Differences in stomatal responses to vapor pressure deficit and/or in soil water content can also explain differences in $W_{\mathrm{I}}$ (Epron and Dreyer 1993; Rasheed et al. 2015). The carbon isotope discrimination occurring during photosynthesis $\left(\Delta^{13} \mathrm{C}\right)$, both during the diffusion of $\mathrm{CO}_{2}$ controlled by stomatal conductance and during the carboxylation by RubisCO, is a proxy for $W_{\mathrm{I}}$ (Farquhar et al. 1982; Farquhar et al. 1989). Variations in $\Delta^{13} \mathrm{C}$ that are related to variations in $W_{\mathrm{I}}$ account for differences in carbon isotope composition $\left(\delta^{13} \mathrm{C}\right)$ of the plant organic matter, which potentially provides a useful time-integrated proxy of wateruse efficiency both at leaf level $\left(W_{\mathrm{I}}\right)$ and at the whole-plant level (TE, Farquhar and Richards 1984; Condon et al. 1990; Roussel et al. 2009a, b). At the global scale, $\Delta^{13} \mathrm{C}$ is decreasing with decreasing mean annual precipitation (Cernusak et al. 2013), which implies that plants living in drier habitats exhibit higher $W_{\mathrm{I}}$ and TE than plants living in mesic habitats.

The occurrence of a tight correlation between $\Delta^{13} \mathrm{C}$ recorded in leaves and TE implies that the leaf-level processes that are driving variations in $W_{\mathrm{I}}$ are also controlling the timeintegrated TE at whole-plant level (Cernusak et al. 2009). While consistent rankings between TE and either $W_{\mathrm{I}}$ or $\Delta^{13} \mathrm{C}$ have often been observed among genotypes within a given species (Roussel et al. 2009a; Fichot et al. 2011; Rasheed et al. 2013; Rasheed et al. 2015), variations in $\Delta{ }^{13} \mathrm{C}$ explained only a fraction of the variation in TE among species (28\% only among three neotropical tree species, for example, Cernusak et al. 2009). There is therefore still a need for careful investigations on the ability of leaf level $\Delta^{13} \mathrm{C}$ records to represent the interspecific variability of wholeplant TE.

Acacia (sensu lato) is a polyphyletic genus comprising over 1300 species worldwide. Acacias can be found from the humid tropics to the arid areas close to African and Australian deserts. These species bear either pinnate leaves or phyllodes resulting from a transformed petiole with as a consequence a very different anatomy. The systematics of the genus have been the matter of severe debates among botanists (Miller and Seigler 2012). The current consensus defining a genus Acacia present mainly in Australia (around 900 species usually bearing phyllodes) and several smaller genera present in Africa and Latin America (Senegalia, Vachelia, Faidherbia, among others).

Water-use efficiency was only seldom investigated in these species. At ecosystem level, the inherent daily water-use efficiency recorded in arid-zone Acacia savanna woodlands dominated by Acacia aneura varied to a large extent with vapor pressure deficit and soil water availability (Eamus et al. 2013). At leaf level, water-use efficiency was larger in phyllodebearing Acacia species (Acacia mangium and Acacia auriculiformis) than in Eucalyptus (Novriyanti et al. 2012). Despite the large distribution of the Acacia species in Australia and in Sahelian Africa and the diversity in forms, growth, and tolerance to water shortage, we are not aware of any systematic survey of water-use efficiency across species and of the relationships between intrinsic water-use efficiency at leaf level and transpiration efficiency at whole-plant level.

To tackle this question, we hypothesized that large interspecific differences in $\Delta^{13} \mathrm{C}, W_{\mathrm{I}}$, and TE exist among these species and that they are related to the climate condition prevailing in their origins. We further postulated that differences in specific leaf area, nitrogen content, stomatal density, and stomatal dimension between pinnate leaves and phyllodes are influencing the relationships between $\Delta^{13} \mathrm{C}, W_{\mathrm{I}}$, and TE. We selected five Australian and four Sahelian species from a very large range of aridity as computed from de Martonne's index (de Martonne 1922), and recorded $\Delta^{13} \mathrm{C}$ and $W_{\mathrm{I}}$ at leaf level and TE at whole-plant level. Seedlings were grown in pots in a greenhouse to compare TE integrated over a 5-month period with $W_{\mathrm{I}}$ estimated from instantaneous measurements of leaf gas exchange and $\Delta^{13} \mathrm{C}$ computed from either $\delta^{13} \mathrm{C}$ of bulk foliage or cellulose extracted from the foliage.

\section{Material and methods}

\subsection{Plant material and growth conditions}

Seedlings of nine Acacia species were grown from seeds in a naturally illuminated greenhouse at Champenoux (France) in 4-L pots filled with a mixture $(1: 1 \mathrm{v} / \mathrm{v})$ of peat and sand and fertilized with $18 \mathrm{~g}$ of a slow releaser fertilizer (Nutricote 100, 13/13/13 N/P/K with oligo-elements). The pot surface was covered with a $2.5-\mathrm{cm}$ layer of perlite to limit direct evaporation from the soil surface. Water content of the substrate at field capacity was assessed by watering the pots until water dripped and by oven-drying at $105^{\circ} \mathrm{C}$ soil samples collected one night after watering.

Five Australian species were provided by the Australian Tree Seed Centre, CSIRO Forest Biosciences, Kingston ACT 2604, Australia. Four of them display phyllodes already at seedling stages (A. aneura F. Muell. ex Benth., Acacia trineura F. Muell., A. mangium Willd., Acacia melanoxylon R. Br.) and one displays only pinnate leaves (Acacia dealbata Link). The four other species, provided by Millennium Seed Bank, Royal Botanic Gardens, Kew, UK, were from Sahelian countries (Acacia senegal L. Willd., Acacia seyal Delile, Acacia raddiana Savi and Acacia albida Del). All Sahelian species display only pinnate leaves. Information about the 
climate at origins of seeds and the new names of the species are provided in Table 1.

Seeds were soaked with $95 \%$ sulfuric acid for 5 to $25 \mathrm{~min}$ and imbibed with water for 6 to $48 \mathrm{~h}$ depending on the hardness of the tegument. Germinated seeds were transferred to the pots. The pots were distributed on a greenhouse table under a randomized block design, with eight blocks containing each one individual of each species. Three pots without plants and three pots with maize seedlings were included in this randomized design. Minimal and maximal air temperatures in the greenhouse were set at 15 and $30^{\circ} \mathrm{C}$ respectively.

Eight seedlings of each species were grown for 5 months. Soil water content was maintained at $80 \%$ of the field capacity by weighing each pot at $0.1 \mathrm{~g}$ (Sartorius-AG Göttingen, QC65EDE-D Germany) every 2 days and adding the required amount of water to reach $80 \%$ field capacity.

\subsection{Leaf gas exchange, intrinsic water-use efficiency, and stomatal traits}

Net $\mathrm{CO}_{2}$ assimilation rate $\left(A_{\text {sat }}\right)$ and stomatal conductance $\left(g_{\text {sat }}\right)$ were measured under saturating irradiance on one leaf or phyllode per seedlings, 1 week before the final harvest. Measurements were conducted with a portable photosynthesis system (Li6400; Li-Cor; Lincoln, USA) using a $6-\mathrm{cm}^{2}$ chamber illuminated by blue-red LEDs. Preliminary light response curves indicated that photosynthesis was almost fully saturated at a photosynthetic photon flux density of $1000 \mu \mathrm{mol} \mathrm{m} \mathrm{m}^{-2} \mathrm{~s}^{-1}$, which was therefore chosen for the measurements. Other standardized conditions during measurements were as follows: $\mathrm{CO}_{2}$ mole fraction at chamber inlet set at $370 \mu \mathrm{mol} \mathrm{mol}{ }^{-1}$, leaf temperature maintained at $25{ }^{\circ} \mathrm{C}$, and vapor pressure deficit kept between 1.0 and $1.5 \mathrm{kPa}$. Intrinsic water-use efficiency at leaf level $\left(W_{\mathrm{I}}\right)$ was computed as $A_{\text {sat }} / g_{\text {sat }}$.

Leaves were collected immediately after leaf gas exchange measurements, stored at $-20{ }^{\circ} \mathrm{C}$, and used to estimate stomatal density (SD) and length (SL). Three $1-\mathrm{cm}^{2}$ disks per leaf were examined under a controlledpressure scanning electron microscope (model 1450VP, Leo, Cambridge, UK) as previously described (Rasheed et al. 2013). As Acacia leaves are amphistomatous, the adaxial and abaxial sides of each disk were observed. Stomata were counted on 30 selected microphotographs for five individuals per species with an image analysis software (VISILOG 6.3, Noesis, Orsay, France). Lengths of 20 stomata were measured on each image.

\subsection{Whole-plant biomass, transpiration, and transpiration efficiency}

Seedlings were harvested; separated into roots, stem, and foliage; oven-dried at $60^{\circ} \mathrm{C}$ for 3 days; and weighed. The area of subset of 10 leaves or phyllodes was previously estimated either by scanning leaflets for pinnate leaves or using an area meter (Li-Cor area meter, A1000 Li-Cor, Lincoln, NE, USA) for phyllodes.

Whole-plant transpiration $(T)$ of each pot was recorded as the difference in weight between two consecutive measurements every second day, cumulated over the entire experiment, and corrected from evaporation averaged for the three unplanted pots. Transpiration efficiency (TE) was computed by dividing biomass at harvest (corrected from initial seed mass) by cumulated wholeplant transpiration.
Table 1 Foliage type of five Australian and four Sahelian Acacia sensu lato species and main climate characteristics of the weather station (city names followed by the state code for Australia and by the ISO 3622 country code for Africa) nearest to place of seed collection. The consensus names for the species after the Melbourne Botanical Congress (Smith and Figueiredo 2011) were added. Annual precipitation $(P)$ average over 30 years, number of dry month (DM) determined as the number of month with monthly precipitation lower than twice the monthly averaged air temperature, and the Martonne aridity index $\left(A_{\mathrm{M}}\right)$ calculated as $P /(T+10)$ with $T$ the annual averaged air temperature

\begin{tabular}{|c|c|c|c|c|c|c|}
\hline Species (old names) & Consensus names & Foliage & Weather stations & $P(\mathrm{~mm})$ & $\mathrm{DM}$ & $A_{\mathrm{M}}$ \\
\hline Acacia trineura F. Muell. & A. trineura F. Muell. & Phyllodes & Mildura, Vic, AU & 287 & 9 & 10 \\
\hline A. aneura F. Muell. & A. aneura F. Muell. & Phyllodes & Charville, Qld, AU & 500 & 6 & 15 \\
\hline A. dealbata Link. & A. dealbata Link. & Leaves & Canberra, ACT, AU & 623 & 0 & 25 \\
\hline A. melanoxylon $\mathrm{R}$. Br. & A. melanoxylon $\mathrm{R}$. Br. & Phyllodes & Mount Gambier, SA, AU & 710 & 3 & 27 \\
\hline A. mangium Willd. & A. mangium Willd. & Phyllodes & Cairns, Qld, AU & 2064 & 3 & 63 \\
\hline A. raddiana Savi & Vachelialis tortilis spp. raddiana (Savi) Kyal. \& Boatwr. & Leaves & Bilma, NE & 12 & 12 & 1 \\
\hline A albida Del & Faidherbia albida (Del.) Chev. & Leaves & Mopti, ML & 467 & 9 & 14 \\
\hline A. senegal L. Willd. & Senegalia senegal (L.) Britton & Leaves & Ouagadougou, BF & 668 & 7 & 24 \\
\hline A. seyal Del. & Vachelia seyal (Del.) PJH Hurter & Leaves & Ouagadougou, BF & 668 & 7 & 24 \\
\hline
\end{tabular}

Data collected on Météo-France (http://monde.meteofrance.com/monde/climat) and weatherzone (http://www.weatherzone.com.au/climate) websites 


\subsection{Carbon isotope discrimination}

Leaflets or phyllodes were finely ground, and $1 \mathrm{mg}$ was enclosed in tin capsules and analyzed with an elemental analyzer (Carlo Erba, NA 1500-NC, Milan, Italy) coupled to an isotope-ratio mass spectrometer (Finnigan, Delta $\mathrm{S}$, Bremen, Germany) for carbon isotope composition $\left(\delta^{13} \mathrm{C}\right)$ and nitrogen content.

Leaflet or phyllode powder $(75 \mathrm{mg}$ ) was first extracted at $120{ }^{\circ} \mathrm{C}$ in $2.0 \mathrm{ml}$ acetic acid $(80 \% v / v)$ and $0.2 \mathrm{ml}$ concentrated nitric acid (69\% $/ / v$ ), and after centrifugation, the pellet was washed with ethanol and then with water (Brendel et al. 2000). Cellulose was then extracted using the acidified sodium chlorite extraction method (Leavitt and Danzer 1993). One milligram of the extracted cellulose was weighed into tin capsules and analyzed as above.

${ }^{13} \mathrm{C}$ discrimination $\left(\Delta^{13} \mathrm{C}\right)$ was calculated as

$\Delta^{13} \mathrm{C}=\frac{\delta^{13} \mathrm{C}_{\text {air }}-\delta^{13} \mathrm{C}_{\text {plant }}}{1+\frac{\delta^{13} \mathrm{C}_{\mathrm{air}}}{1000}}$

$\delta^{13} \mathrm{C}_{\text {air }}$ was estimated using the $\delta^{13} \mathrm{C}$ of maize leaves $-12.6 \%$ \pm 0.09 according to Marino and McElroy (1991):

$\delta^{13} \mathrm{C}_{\text {air }}=3.3+\delta^{13} \mathrm{C}_{\text {maize }}$

\subsection{Theory}

$W_{\mathrm{I}}$ and $\Delta^{13} \mathrm{C}$ are both related to the ratio between intercellular $\left(c_{\mathrm{i}}\right)$ and atmospheric $\left(c_{\mathrm{a}}\right) \mathrm{CO}_{2}$ mole fraction (Farquhar and Richards 1984):

$W_{\mathrm{I}}=\frac{c_{\mathrm{a}} \times\left(1-{ }^{c_{\mathrm{i}}} / c_{\mathrm{a}}\right)}{1.6}$

and

$\Delta^{13} \mathrm{C}=(a-d)+(b-a) \times{ }^{c_{\mathrm{i}}} / c_{\mathrm{a}}$

1.6 is the ratio of diffusivities for water vapor and $\mathrm{CO}_{2}$ in air, $a$ is the fractionation occurring during the diffusion through stomata $(4.4 \%)$, and $b$ is the fractionation occurring during carboxylation by RubisCO and phosphoenol pyruvate carboxylase in C3 plants (27 \%o). The parameter $d$ combines all other fractionation related to the dissolution of $\mathrm{CO}_{2}$, liquid phase diffusion, photorespiration, and dark respiration
(Farquhar et al. 1989). Combining Eqs. 3 and 4 relates $W_{\mathrm{I}}$ to $\Delta^{13} \mathrm{C}$ :

$W_{\mathrm{I}}=\frac{c_{\mathrm{a}} \times\left(b-d-\Delta^{13} \mathrm{C}\right)}{1.6 \times(b-a)}$

The latter equation can be rearranged:

$W_{\mathrm{I}}=-m \times \Delta^{13} \mathrm{C}+m \times(b-d)$

The slope of the linear relationship between $W_{\mathrm{I}}$ and $\Delta^{13} \mathrm{C}$ is $m$, and the intercept is $\mathrm{m} \times(b-d)$, with

$m=\frac{c_{\mathrm{a}}}{1.6(b-a)}$

Finally, TE can be related to $W_{\mathrm{I}}$ by taking into account the leaf-to-air water vapor mole fraction difference $(w)$, the carbon-use efficiency (CUE, which is the fraction of carbon assimilated recovered in plant biomass, thus not lost by respiration), and the ratio of unproductive to productive water loss $\left(\Phi_{\mathrm{W}}\right)$ (Farquhar and Richards 1984):

$\mathrm{TE}=\frac{W_{\mathrm{I}}}{w} \times \frac{\mathrm{CUE}}{\left(1+\Phi_{\mathrm{W}}\right)}$

Day-time foliar transpiration is the productive water loss while night-time transpiration and soil evaporation are unproductive water loss (i.e., water loss without associated carbon gain). In this study, whole-plant transpiration was corrected for soil evaporation.

\subsection{Data analyses}

One way analyses of variance were run to characterize the variation of each measured trait among the nine species or between plants bearing pinnate leaves or phyllodes. The normality of the distribution of residuals was tested using the Shapiro-Wilk test. Mean and standard error of the mean were calculated. Pearson correlation coefficients $(r)$ between averaged values of measured traits for each species were calculated and taken as significant when $P<0.05$. Changes in species ranking were analyzed with Spearman rank correlation coefficients $(\rho)$. All statistical analyses were made with the $\mathrm{R}$ software (R Core Team 2016).

\section{Results}

\subsection{Interspecific variations in ${ }^{13} \mathrm{C}$ discrimination during photosynthesis $\left(\Delta^{13} \mathrm{C}\right)$}

A large variation in bulk leaf $\Delta^{13} \mathrm{C}$ was observed among the nine studied species, from $19.6 \%$ in A. senegal to $23.9 \%$ in $A$. aneura (Table 2). A direct comparison 
Table 2 Mean values (and their standard errors) recorded with 8 seedlings of five Australian and four Sahelian Acacia s.l. species: ${ }^{13} \mathrm{C}$ discrimination recorded in bulk leaf material $\left(\Delta^{13} \mathrm{C}\right), \mathrm{N}$ content in leaves per unit mass $(\mathrm{N})$, and per unit area $\left(\mathrm{N}_{\mathrm{A}}\right)$, specific leaf area
(SLA), net $\mathrm{CO}_{2}$ assimilation rate under saturating irradiance $\left(A_{\mathrm{sat}}\right)$, stomatal conductance under saturating irradiance $\left(g_{\text {sat }}\right)$, intrinsic wateruse efficiency $\left(W_{\mathrm{I}}=A_{\text {sat }} / g_{\text {sat }}\right)$, stomatal density over the two leaf surfaces (SD), stomatal length (SL), and transpiration efficiency (TE)

\begin{tabular}{|c|c|c|c|c|c|c|c|c|c|c|}
\hline Species & $\begin{array}{l}\Delta_{\% o}^{13} \mathrm{C} \\
\text { D. }\end{array}$ & $\begin{array}{l}\mathrm{N} \\
\%\end{array}$ & $\begin{array}{l}\mathrm{N}_{\mathrm{A}} \\
\mathrm{g} \mathrm{m}^{-2}\end{array}$ & $\begin{array}{l}\text { SLA } \\
\mathrm{m}^{2} \mathrm{~kg}^{-1}\end{array}$ & 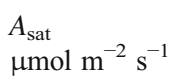 & $\begin{array}{l}g_{\text {sat }} \\
\text { mol m} ~^{-2} \mathrm{~s}^{-1}\end{array}$ & $\begin{array}{l}W_{\mathrm{I}} \\
\mu \mathrm{mol} \mathrm{mol}\end{array}$ & $\begin{array}{l}\mathrm{SD} \\
\mathrm{mm}^{-2}\end{array}$ & $\begin{array}{l}\text { SL } \\
\mu \mathrm{m}\end{array}$ & $\begin{array}{l}\text { TE } \\
\mathrm{g} \mathrm{kg}^{-1}\end{array}$ \\
\hline A. aneura & $23.9 \pm 0.1$ & $4.1 \pm 0.1$ & $4.4 \pm 0.1$ & $9.3 \pm 0.4$ & $21.0 \pm 0.8$ & $0.52 \pm 0.04$ & $41 \pm 2$ & $625 \pm 26$ & $14.5 \pm 0.3$ & $3.3 \pm 0.3$ \\
\hline A. mangium & $22.4 \pm 0.1$ & $3.3 \pm 0.2$ & $2.5 \pm 0.2$ & $13.3 \pm 0.2$ & $13.7 \pm 1.4$ & $0.29 \pm 0.05$ & $54 \pm 6$ & $617 \pm 26$ & $9.8 \pm 0.2$ & $4.7 \pm 0.1$ \\
\hline A. melanoxylon & $20.4 \pm 0.2$ & $2.8 \pm 0.2$ & $2.6 \pm 0.2$ & $11.0 \pm 0.5$ & $12.9 \pm 0.7$ & $0.16 \pm 0.02$ & $82 \pm 5$ & $587 \pm 22$ & $8.3 \pm 0.2$ & $6.3 \pm 0.2$ \\
\hline A. trineura & $22.9 \pm 0.3$ & $4.1 \pm 0.2$ & $7.7 \pm 0.2$ & $7.5 \pm 1.2$ & $15.0 \pm 1.6$ & $0.39 \pm 0.09$ & $61 \pm 14$ & $531 \pm 37$ & $10.3 \pm 0.4$ & $4.6 \pm 0.2$ \\
\hline A. dealbata & $21.6 \pm 0.3$ & $3.1 \pm 0.1$ & $3.0 \pm 0.1$ & $10.9 \pm 0.8$ & $18.5 \pm 1.9$ & $0.36 \pm 0.06$ & $60 \pm 9$ & $448 \pm 9$ & $11.4 \pm 0.4$ & $5.5 \pm 0.2$ \\
\hline A. raddiana & $22.8 \pm 0.4$ & $4.5 \pm 0.2$ & $5.9 \pm 0.1$ & $8.5 \pm 1.2$ & $22.7 \pm 1.8$ & $0.53 \pm 0.08$ & $48 \pm 6$ & $251 \pm 19$ & $16.3 \pm 0.8$ & $3.6 \pm 0.2$ \\
\hline A. senegal & $19.6 \pm 0.2$ & $5.1 \pm 0.3$ & $5.7 \pm 0.3$ & $10.7 \pm 1.6$ & $14.3 \pm 1.4$ & $0.16 \pm 0.02$ & $96 \pm 9$ & $526 \pm 52$ & $8.0 \pm 0.2$ & $4.7 \pm 0.5$ \\
\hline A. seyal & $21.5 \pm 0.3$ & $3.2 \pm 0.1$ & $3.4 \pm 0.1$ & $9.8 \pm 0.6$ & $14.1 \pm 0.6$ & $0.19 \pm 0.03$ & $80 \pm 8$ & $319 \pm 13$ & $16.3 \pm 0.5$ & $4.3 \pm 0.2$ \\
\hline A. albida & $22.1 \pm 0.2$ & $5.0 \pm 0.2$ & $4.2 \pm 0.2$ & $15.8 \pm 0.6$ & $19.1 \pm 0.6$ & $0.37 \pm 0.03$ & $55 \pm 5$ & $342 \pm 11$ & $10.2 \pm 0.7$ & $4.1 \pm 0.3$ \\
\hline ANOVA & $* * *$ & $* * *$ & $* *$ & $* *$ & $* * *$ & $* * *$ & $* *$ & $* * *$ & $* * *$ & $* * *$ \\
\hline
\end{tabular}

Stars indicate between-species differences at $p=0.01(* *)$ and $p=0.001(* * *)$

showed that the leaf type (phyllodes versus pinnate leaves) had only a minor influence, with phyllodes exhibiting slightly higher $\Delta^{13} \mathrm{C}$ than pinnate leaves $\left(+0.7 \%\right.$ on average). $\Delta^{13} \mathrm{C}$ computed from leaf cellulose isotope composition was on average $1.0 \% \pm 0.1$ lower than that when computed from bulk leaf material, with no difference between pinnate leaves and phyllodes $(p=0.5)$. The same species ranking was observed $(\rho=1$, Fig. 1$)$ and the slope of the linear regression line $(1.1 \pm 0.1)$ was not significantly different from 1 at $p=0.05$.

\subsection{Intrinsic water-use efficiency at leaf level $\left(W_{\mathrm{I}}\right)$}

Variations in $\Delta^{13} \mathrm{C}$ among species were highly and negatively correlated with variations in $W_{\mathrm{I}}(r=-0.94, p<0.001$, Fig. 2a), and the species ranking was conserved $(\rho=-0.83, p<0.01)$. Across species, $\Delta{ }^{13} \mathrm{C}$ was correlated to stomatal conductance under saturating irradiance ( $g_{\text {sat }}, r=0.87, p<0.01$, Fig. $2 \mathrm{~b}$ ) while the correlation between $\Delta{ }^{13} \mathrm{C}$ and net $\mathrm{CO}_{2}$ assimilation under saturating irradiance $\left(A_{\text {sat }}\right)$ was not significant $(p=0.07$, Fig. 2c) nor were all nonlinear regressions we tested.

Despite large interspecific differences in leaf nitrogen content, both on a per dry mass and per area basis, specific leaf area, stomatal density, and stomatal length (Table 2), $\Delta^{13} \mathrm{C}$ and $W_{\mathrm{I}}$ were not correlated to any of these leaf traits (data not shown). Across species, phyllodes contained lower nitrogen concentration (per unit mass) than pinnate leaves $(p<0.01)$, but similar nitrogen content per unit area and similar specific leaf area (Table 2). They also exhibited a higher stomatal density $(p<0.001)$ and a slightly lower stomatal length $(p<0.05) . A_{\text {sat }}, g_{\text {sat }}$, and $W_{\mathrm{I}}$ were not significantly different between phyllodes and pinnate leaves.

\subsection{Transpiration efficiency at whole-plant level (TE)}

The biomass produced during the experiment $(B)$ was tightly and positively correlated to the cumulated amount of water used during growth $(T)$ across the nine species $(r=0.98$, $p<0.001$, Fig. 3a). The lowest biomass and water use were recorded in A. aneura and the highest in A. dealbata. Because the relationship between $B$ and $T$ showed a positive intercept $(1.24 \pm 0.49, p<0.05)$, TE was positively correlated to $B$ $(r=0.86, p<0.01$, Fig. $3 \mathrm{~b})$ and, to a lesser extent, to $T$ $(r=0.79, p<0.05$, Fig. 3c). The lowest TE was observed in $A$. aneura and A. raddiana and the highest in A. mangium and A. dealbata (Table 2).

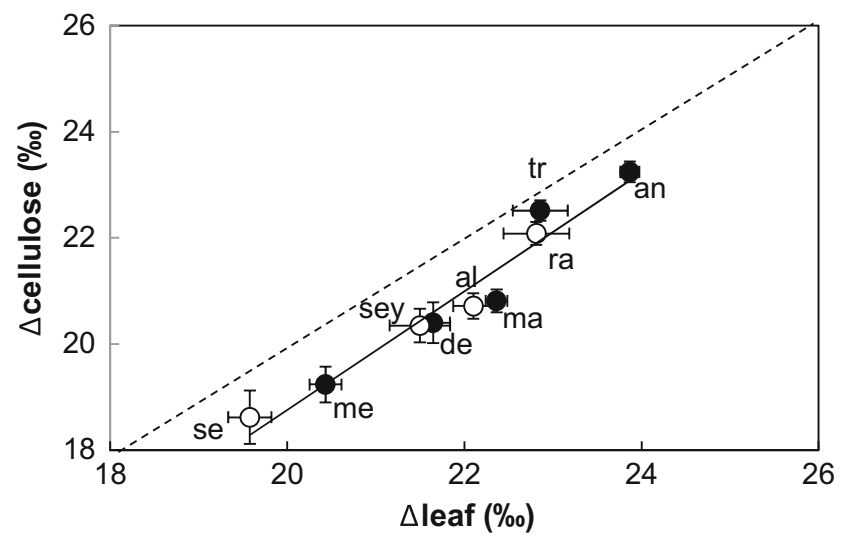

Fig. 1 Relationship between carbon isotope discrimination recorded on bulk leaf tissues $\left(\Delta_{\text {leaf }}\right)$ and on the cellulose extracted from the leaves ( $\left.\Delta_{\text {cellulose }}\right)$ for five Australian (closed circles) and four Sahelian (open circles) Acacia species. The dashed line represents the 1:1 line. The full line represents the linear regression on mean values. Horizontal and vertical bars represent the standard errors of the mean of 8 seedlings for each species. The first letters of the species name is located closed to its symbol 

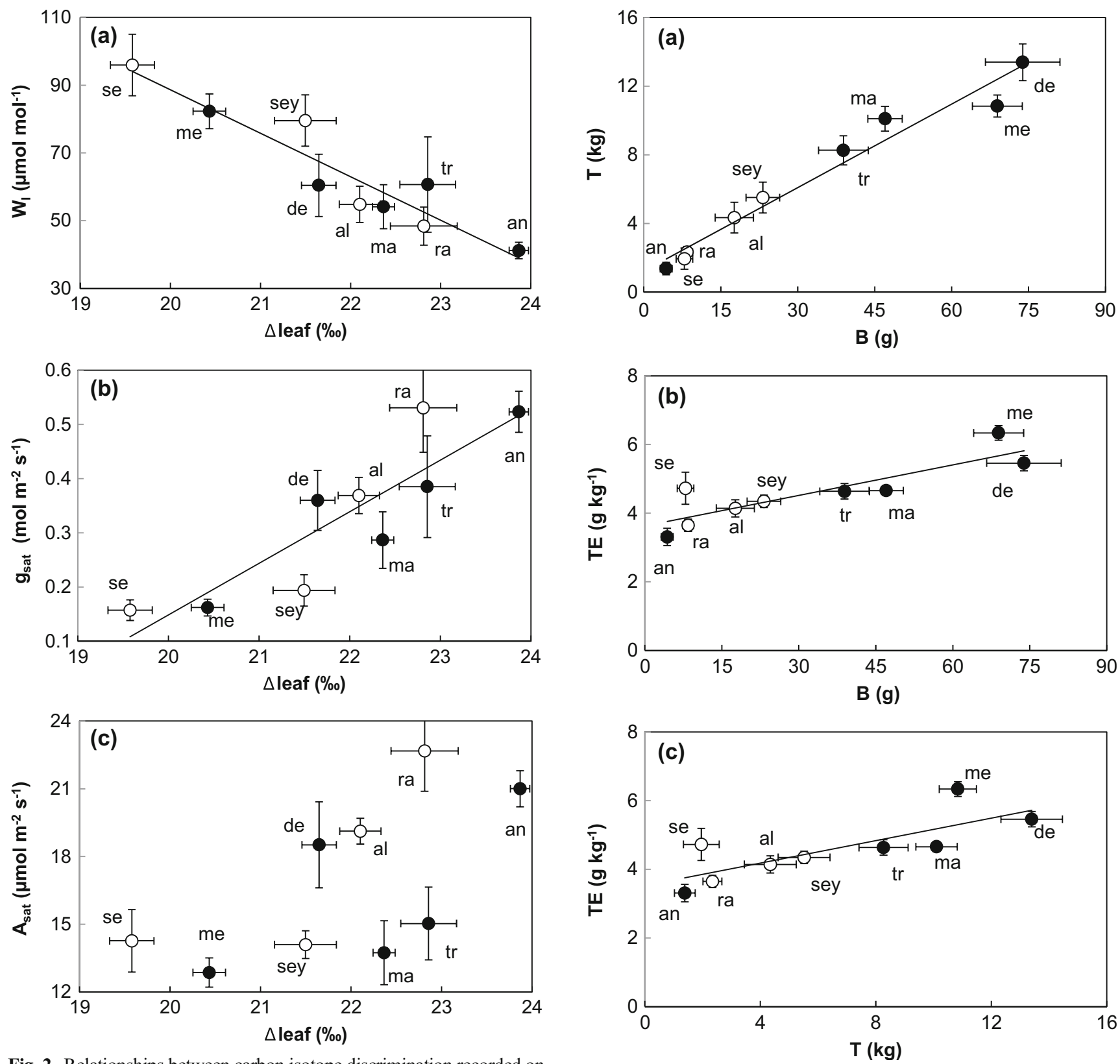

Fig. 2 Relationships between carbon isotope discrimination recorded on bulk leaf tissues ( $\Delta$ leaf) and a intrinsic water-use efficiency $\left(W_{\mathrm{I}}\right), \mathbf{b}$ stomatal conductance under saturating irradiance $\left(\mathrm{g}_{\text {sat }}\right)$, and $\mathbf{c}$ net $\mathrm{CO}_{2}$ assimilation under saturating irradiance $\left(A_{\text {sat }}\right)$ for five Australian (closed circles) and four Sahelian (open circles) Acacia species. The full line represents the linear regression on mean values when the correlation coefficient was significantly different from 0 at $p=0.05$. Horizontal and vertical bars represent the standard errors of the mean of 8 seedlings for each species. The first letters of the species name is located closed to its symbol

In contrast to $W_{\mathrm{I}}$, variations in $\mathrm{TE}$ among the nine Acacia species were poorly related to variations in $\Delta{ }^{13} \mathrm{C}(r=-0.65, p=0.05$, Fig. 4a). But the correlation was much better when Australian and Sahelian species were considered separately $(r=-0.99$ and -0.95 for Australian and Sahelian species respectively, $p<0.05$ ),

Fig. 3 Relationships between total seedling biomass at harvest $(B)$ and a cumulated amount of water used during growth $(T)$ and $\mathbf{b}$ transpiration efficiency (TE), and $\mathbf{c}$ relationship between cumulated amount of water used during growth $(T)$ and transpiration efficiency (TE) for five Australian (closed circles) and four Sahelian (open circles) Acacia species. The full line represents the linear regression on mean values. Horizontal and vertical bars represent the standard errors of the mean of 8 seedlings for each species. The first letters of the species name is located closed to its symbol

and species ranking was perfectly preserved ( $\rho=-1$ for each group of species).

Similarly, the correlation between TE and $W_{\mathrm{I}}$ among the nine species was not significant $(p>0.05)$ while tight correlations were observed for Australian and Sahelian species considered independently ( $\rho$ of respectively 0.95 and 0.94 , 

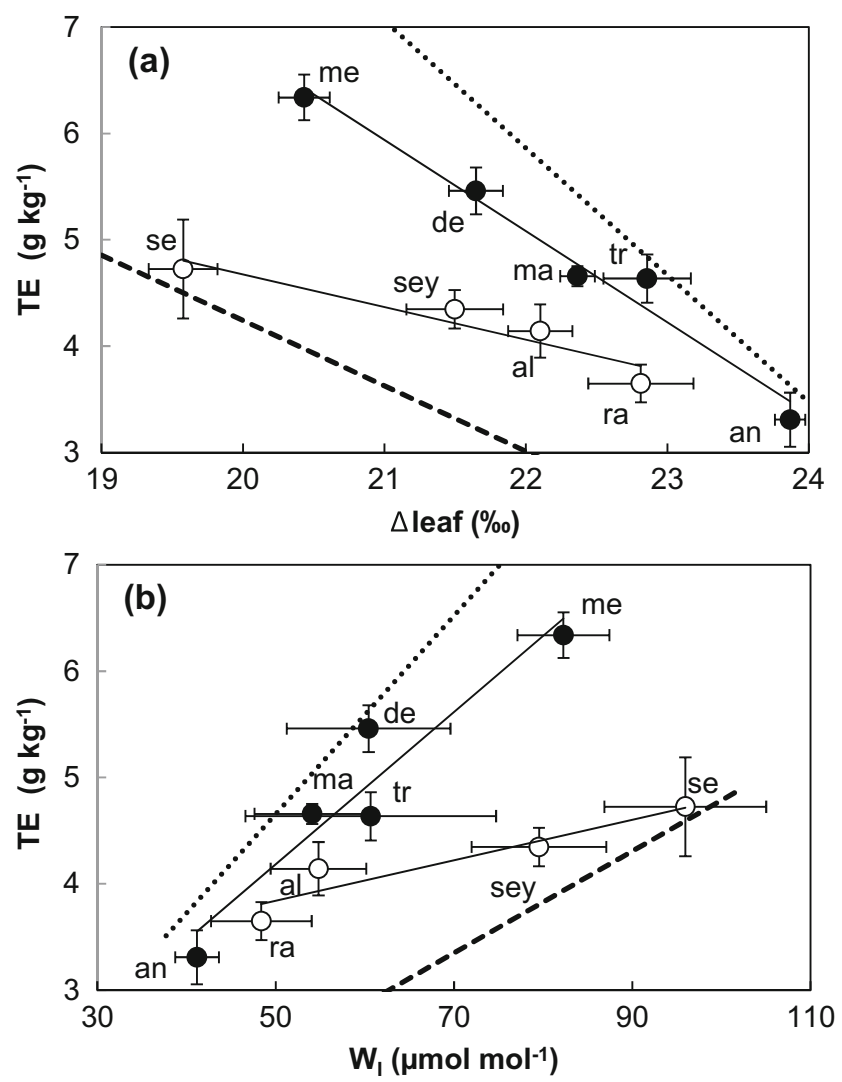

Fig. 4 Relationship between transpiration efficiency (TE) and a carbon isotope discrimination recorded on bulk leaf tissues ( $\Delta$ leaf) and $\mathbf{b}$ intrinsic water-use efficiency $\left(W_{\mathrm{I}}\right)$ for five Australian (closed circles) and four Sahelian (open circles) Acacia species. The full lines represent the linear regression over mean values for either Australian or Sahelian species. Horizontal and vertical bars represent the standard errors of the mean of 8 seedlings for each species. The dotted lines are the expected relationships when carbon-used efficiency (CUE) is set at 0.55 and the ratio of unproductive to productive water loss $\left(\Phi_{\mathrm{W}}\right)$ at 0.05 . The dashed lines are the expected relationships with CUE and $\Phi_{\mathrm{W}}$ set at 0.35 and 0.25 respectively. Leaf-to-air water vapor mole fraction difference was set at $7.5 \mathrm{mmol} \mathrm{mol}^{-1}$. For a, fractionation occurring during carboxylation was set at $27 \%$ (see "Discussion"). The first letters of the species name is located closed to its symbol

Fig. 4b). The Australian species exhibited higher transpiration efficiency than Sahelian species for a given $\Delta^{13} \mathrm{C}$ or $W_{\mathrm{I}}$.

\section{Discussion}

The $1 \%$ offset in $\Delta^{13} \mathrm{C}$ observed between bulk foliage and extracted cellulose confirmed that cellulose, which has an isotope composition close to that of the primary products of photosynthesis, is more enriched in ${ }^{13} \mathrm{C}$ than other foliage compounds such as lipids and lignin (Bowling et al. 2008). This $1 \%$ offset is similar to the one reported between bulk wood and cellulose in different poplar genotypes in the field (Rasheed et al. 2012; Rasheed et al. 2015). Because species ranking is perfectly respected using $\Delta^{13} \mathrm{C}$ either computed from cellulose or from bulk foliage, $\Delta^{13} \mathrm{C}$ from bulk foliage is providing a consistent proxy for isotope fractionation during photosynthesis, despite the $1 \%$ offset. Interestingly, no difference was evidenced between pinnate leaves and phyllodes, and as a consequence, post-photosynthetic fractionation against ${ }^{13} \mathrm{C}$, if any, had probably similar effects in the nine studied Acacia species.

$\Delta^{13} \mathrm{C}$ and $W_{\mathrm{I}}$ were highly correlated with interspecific differences in $\Delta^{13} \mathrm{C}$ accounting for $87 \%$ of the interspecific differences in $W_{\mathrm{I}}$. This confirms that despite a potential shift in $\Delta{ }^{13} \mathrm{C}$ due to a finite conductance to $\mathrm{CO}_{2}$ transfer in the mesophyll (Barbour et al. 2010; Warren et al. 2011), the ranking of our species was not affected. Moreover, the ratios of the intercept $[m \times(b-d)$, Eq. 6] divided by the opposite number of the slope $(m)$ of the linear regression between $\Delta^{13} \mathrm{C}$ and $W_{\mathrm{I}}$ were very similar $\left(b-d=26.9\right.$ or $27.2 \%$ with $\Delta^{13} \mathrm{C}$ computed from either isotope composition of bulk foliage, Fig. 2a, or extracted cellulose) and were not different from the expected net fractionation occurring during carboxylation in $\mathrm{C} 3$ leaves (27\%o, Farquhar et al. 1982), including a marginal contribution (5\%) of phosphoenolpyruvate carboxylase (Evans et al. 1986). This implies that parameter $d$ in Eq. 6 is close to zero and that post-photosynthetic fractionations or mesophyll conductance have limited impacts on foliage isotope composition under the present conditions.

A large range in $\Delta^{13} \mathrm{C}(19.6-23.9 \%)$ was observed between the nine Acacia species. This $4.3 \%$ range is much larger than that reported between genotypes of Populus deltoides $\times$ Populus nigra (Monclus et al. 2005; Marron et al. 2005), of Prosopis glandulosa (Pennington et al. 1999) and of Quercus robur (Brendel et al. 2008) or between sapling of tropical tree species (Cernusak et al. 2009). This large range in $\Delta^{13} \mathrm{C}$ is well-reflected in a large range of $W_{\mathrm{I}}$ among the nine species (41-96 $\mu \mathrm{mol} \mathrm{mol}^{-1}$ ), but these variations were not related to the climate condition prevailing in their origins.

Interspecific variations in $\Delta^{13} \mathrm{C}$ and $W_{\mathrm{I}}$ were closely related to variations in light-saturated stomatal conductance, but not to variations in light-saturated photosynthesis nor to variation in leaf nitrogen content or specific leaf area. Variations in $W_{\mathrm{I}}$ among oak and poplar genotypes were also driven by variation in stomatal conductance, but while these variations were reflecting variation in stomatal density among genotypes (Monclus et al. 2006; Roussel et al. 2009b), this was not the case between our nine Acacia species. It is often postulated that light-saturated stomatal conductance is influenced by stomatal density (Nobel 2005), but this does not hold for the different Acacia species in this study. Higher stomatal density in phyllodes than in pinnate leaves does not confer higher stomatal conductance in phyllode-bearing Acacia species, maybe because the higher stomatal density is partly offset by smaller stomatal length (Hetherington and Woodward 2003).

The range of TE between the nine Acacia species (3.3$6.3 \mathrm{~g} \mathrm{~kg}^{-1}$ ) was narrower than the range of $W_{\mathrm{I}}$, and TE was poorly correlated to $\Delta^{13} \mathrm{C}$ and $W_{\mathrm{I}}$ when all species were 
combined. Transpiration is controlled by stomatal conductance but is modulated by leaf-to-air water vapor mole fraction difference ( $w$ in Eq. 8). However, no large difference in $w$ may be expected in this experiment that was carried out in a wellventilated greenhouse with a randomized block design. At whole-plant level, TE depends on carbon-use efficiency (CUE), the fraction of assimilated carbon that is not lost through respiration and on the fraction of water loss that is not associated with photosynthesis (Farquhar et al. 1989). Interestingly, the correlations between TE and either $\Delta^{13} \mathrm{C}$ or $W_{\mathrm{I}}$ were only significant when Australian and Sahelian species were considered separately. A correlation between TE and $\Delta^{13} \mathrm{C}$ has already been observed at the species level, either on individuals of a tropical pioneer tree species exposed to different levels of soil fertility (Cernusak et al. 2007), different provenances of A. albida (Roupsard et al. 1998), or different genotypes of poplar (Rasheed et al. 2013; Rasheed et al. 2015) and oak (Roussel et al. 2009a). The different relationship observed between Australian and Sahelian species was not related to the type of photosynthetic organs because the Australian A. dealbata that bears pinnate leaves clearly fits on the relationship for Australian species bearing phyllodes, not on the relationship for Sahelian species bearing pinnate leaves. Thus, a putative difference in cuticular or night-time stomatal transpiration between phyllodes and pinnate leaves is unlikely accounting for the difference between Australian and Sahelian species. Cuticular water loss is thought to be negligible compared to night-time stomatal transpiration (Cernusak et al. 2007). Night-time transpiration is typically 5 to $15 \%$ of day-time transpiration $\left(\Phi_{\mathrm{W}}\right.$, Caird et al. 2007) and night-time transpiration varied from 15 to $22 \%$ of total transpiration ( $\Phi_{\mathrm{W}}$ from 0.18 to 0.28 ) among eight tree species from the Brazilian cerrado (Bucci et al. 2005). In addition, carbon-use efficiency of trees ranges between 0.35 and 0.55 (Gifford 2003). Variations in CUE and relative nighttime stomatal transpiration within these ranges may account for the variability of TE $\Delta^{13} \mathrm{C}$ (Fig. 4a) or TE $W_{\mathrm{I}}$ (Fig. 4b) among our nine species. However, the firm explanation accounting for higher TE at a given $W_{\mathrm{I}}$ in greenhouse-grown seedlings of Australian Acacia species compared to Sahelian Acacia species deserves further investigations.

\section{Conclusion}

A large interspecific difference in $\Delta^{13} \mathrm{C}, W_{\mathrm{I}}$, and TE exists among the nine studied Acacia species, but in contrast to our first hypothesis, these differences were not related to the climate condition prevailing in their origins. Differences in nitrogen content and stomatal density between pinnate leaves and phyllodes did not influence the relationships between $\Delta^{13} \mathrm{C}$ and $W_{\mathrm{I}}$. While $\Delta^{13} \mathrm{C}$ was closely related to $W_{\mathrm{I}}$, the relationship between TE and either $\Delta^{13} \mathrm{C}$ or $W_{\mathrm{I}}$ was only significant when Australian and Sahelian species were considered separately, suggesting that differences in carbon-use efficiency or night-time transpiration are potentially affecting the relation between water-use efficiency at leaf level and transpiration efficiency at whole-plant level.

Acknowledgments The authors thank the technicians of UMR EEF, Jean Marie Gioria and Pascal Courtois, for their supports during the greenhouse experiments, and Christophe Bailly (UEFL, Inra) for the maintenance of the greenhouse. The authors also thank the staff (Christian Hossann and Claude Bréchet) of the certified facility in Functional Ecology (PTEF OC 081) for the isotope analyses and the electron microscopy imaging.

\section{Compliance with ethical standards}

Funding Funding was mainly provided by Inra through the UMR EEF. PTEF facility and UMR 1137 EEF are supported by the Laboratory of Excellence ARBRE (ANR-12- LABXARBRE-01). NMK was granted by the Mauritanian government through its Embassy in Paris, France.

\section{References}

Bacon MA (2004) Water use efficiency in plant biology. Blackwell; CRC Press, Boca Raton

Barbour MM, Warren CR, Farquhar GD et al (2010) Variability in mesophyll conductance between barley genotypes, and effects on transpiration efficiency and carbon isotope discrimination. Plant Cell Environ 33:1176-1185. doi:10.1111/j.1365-3040.2010.02138.x

Bowling DR, Pataki DE, Randerson JT (2008) Carbon isotopes in terrestrial ecosystem pools and $\mathrm{CO}_{2}$ fluxes. New Phytol 178:24-40. doi:10.1111/j.1469-8137.2007.02342.x

Brendel O, Iannetta PPM, Stewart D (2000) A rapid and simple method to isolate pure alpha-cellulose. Phytochem Anal 11:710. doi:10.1002/(SICI)1099-1565(200001/02)11:1<7::AIDPCA488>3.0.CO;2-U

Brendel O, Le Thiec D, Scotti-Saintagne C et al (2008) Quantitative trait loci controlling water use efficiency and related traits in Quercus robur L. Tree Genet Genomes 4:263-278. doi:10.1007/s11295007-0107-Z

Bucci SJ, Goldstein G, Meinzer FC et al (2005) Mechanisms contributing to seasonal homeostasis of minimum leaf water potential and predawn disequilibrium between soil and plant water potential in Neotropical savanna trees. Trees 19:296-304. doi:10.1007/s00468004-0391-2

Caird MA, Richards JH, Donovan LA (2007) Nighttime stomatal conductance and transpiration in C3 and C4 plants. Plant Physiol 143: 4-10. doi:10.1104/pp.106.092940

Cernusak LA, Winter K, Aranda J et al (2007) Transpiration efficiency of a tropical pioneer tree (Ficus insipida) in relation to soil fertility. $\mathrm{J}$ Exp Bot 58:3549-3566. doi:10.1093/jxb/erm201

Cernusak LA, Winter K, Aranda J et al (2009) Transpiration efficiency over an annual cycle, leaf gas exchange and wood carbon isotope ratio of three tropical tree species. Tree Physiol 29:1153-1161. doi:10.1093/treephys/tpp052

Cernusak LA, Ubierna N, Winter K et al (2013) Environmental and physiological determinants of carbon isotope discrimination in terrestrial plants. New Phytol 200:950-965. doi:10.1111/nph.12423

Condon AG, Farquhar GD, Richards RA (1990) Genotypic variation in carbon isotope discrimination and transpiration efficiency in wheat. Leaf gas exchange and whole plant studies. Aust J Plant Physiol 17: 9-22. doi:10.1071/PP9900009 
R Core Team (2016) R: a language and environment for statistical computing. R Foundation for Statistical Computing, Vienna

de Martonne E (1922) Abrégé de géographie physique. A. Colin, Paris

Eamus D, Cleverly J, Boulain N et al (2013) Carbon and water fluxes in an arid-zone Acacia savanna woodland: an analyses of seasonal patterns and responses to rainfall events. Agric For Meteorol 182183:225-238. doi:10.1016/j.agrformet.2013.04.020

Epron D, Dreyer E (1993) Long-term effects of drought on photosynthesis of adult oak trees [Quercus petraea (Matt.) Liebl. and Quercus robur L.] in a natural stand. New Phytol 125:381-389

Evans JR, Sharkey TD, Berry JA, Farquhar GD (1986) Carbon isotope discrimination measured concurently with gas exchange to investigate $\mathrm{CO} 2$ diffusion in leaves of higher plants. Aust J Plant Physiol $13: 281-292$

Farquhar G, Richards RA (1984) Isotopic composition of plant carbon correlates with water-use efficiency of wheat genotypes. Aust J Plant Physiol 11:539-552. doi:10.1071/PP9840539

Farquhar GD, O'Leary MH, Berry JA (1982) On the relationship between carbon isotope discrimination and the intercellular carbon dioxide concentration in leaves. Aust J Plant Physiol 9:121-137. doi:10.1071/PP9820121

Farquhar GD, Ehleringer JR, Hubick KT (1989) Carbon isotope discrimination and photosynthesis. Annu Rev Plant Physiol Plant Mol Biol 40:503-537. doi:10.1146/annurev.pp.40.060189.002443

Fichot R, Chamaillard S, Depardieu C et al (2011) Hydraulic efficiency and coordination with xylem resistance to cavitation, leaf function, and growth performance among eight unrelated Populus deltoides x Populus nigra hybrids. J Exp Bot 62: 2093-2106. doi:10.1093/jxb/erq415

Franks PJ, Farquhar GD (2007) The mechanical diversity of stomata and its significance in gas-exchange control. Plant Physiol 143:78-87. doi:10.1104/pp.106.089367

Gifford RM (2003) Plant respiration in productivity models: conceptualisation, representation and issues for global terrestrial carbon-cycle research. Funct Plant Biol 30:171. doi:10.1071/FP02083

Hetherington AM, Woodward FI (2003) The role of stomata in sensing and driving environmental change. Nature 424:901-908. doi:10.1038/nature01843

Leavitt SW, Danzer SR (1993) Method for batch processing small wood samples to holocellulose for stable-carbon isotope analysis. Anal Chem 65:87-89. doi:10.1021/ac00049a017

Marino BD, McElroy MB (1991) Isotopic composition of atmospheric $\mathrm{CO}_{2}$ inferred from carbon in $\mathrm{C} 4$ plant cellulose. Nature 349:127131. doi: $10.1038 / 349127 \mathrm{a} 0$

Marron N, Villar M, Dreyer E et al (2005) Diversity of leaf traits related to productivity in 31 Populus deltoides x Populus nigra clones. Tree Physiol 25:425-435. doi:10.1093/treephys/25.4.425

Miller JT, Seigler D (2012) Evolutionary and taxonomic relationships of Acacia s.l. (Leguminosae: Mimosoideae). Aust Syst Bot 25:217224. doi:10.1071/SB11042

Monclus R, Dreyer E, Delmotte FM et al (2005) Productivity, leaf traits and carbon isotope discrimination in 29 Populus deltoides $\mathrm{x} P$. nigra clones. New Phytol 167:53-62. doi:10.1111/j.14698137.2005.01407.x

Monclus R, Dreyer E, Villar M et al (2006) Impact of drought on productivity and water use efficiency in 29 genotypes of Populus deltoides x Populus nigra. New Phytol 169:765-777. doi:10.1111/j.1469-8137.2005.01630.x
Niinemets Ü (1999) Research review. Components of leaf dry mass per area - thickness and density - alter leaf photosynthetic capacity in reverse directions in woody plants. New Phytol 144:35-47. doi:10.1046/j.1469-8137.1999.00466.x

Nobel PS (2005) Physicochemical and environmental plant physiology, 3rd edn. Elsevier Academic Press, Amsterdam

Novriyanti E, Watanabe M, Makoto K et al (2012) Photosynthetic nitrogen and water use efficiency of acacia and eucalypt seedlings as afforestation species. Photosynthetica 50:273-281. doi:10.1007/s11099-012-0033-7

Pennington RE, Tischler CR, Johnson HB, Polley HW (1999) Genetic variation for carbon isotope composition in honey mesquite (Prosopis glandulosa). Tree Physiol 19:583-589. doi:10.1093/treephys/19.9.583

Rasheed F, Richard B, Le Thiec D et al (2012) Time course of $\delta 13 \mathrm{C}$ in poplar wood: genotype ranking remains stable over the life cycle in plantations despite some differences between cellulose and bulk wood. Tree Physiol 31:1183-1193. doi:10.1093/treephys/tpr108

Rasheed F, Dreyer E, Richard B et al (2013) Genotype differences in ${ }^{13} \mathrm{C}$ discrimination between atmosphere and leaf matter match differences in transpiration efficiency at leaf and whole-plant levels in hybrid Populus deltoides $\times$ nigra. Plant Cell Environ 36:87-102. doi:10.1111/j.1365-3040.2012.02556.x

Rasheed F, Dreyer E, Richard B et al (2015) Vapour pressure deficit during growth has little impact on genotypic differences of transpiration efficiency at leaf and whole-plant level: an example from Populus nigra L.: VPD and the genetic variability of transpiration efficiency in poplar. Plant Cell Environ 38:670-684. doi: $10.1111 /$ pce. 12423

Reich PB, Ellsworth DS, Walters MB (1998) Leaf structure (specific leaf area) modulates photosynthesis-nitrogen relations: evidence from within and across species and functional groups. Funct Ecol 12: 948-958. doi:10.1046/j.1365-2435.1998.00274.x

Roupsard O, Joly HI, Dreyer E (1998) Variability of initial growth, wateruse efficiency and carbon isotope discrimination in seedlings of Faidherbia albida (Del.) A. Chev., a multipurpose tree of semiarid Africa. Provenance and drought effects. Ann For Sci 55:329 348. doi:10.1051/forest: 19980305

Roussel M, Dreyer E, Montpied P et al (2009a) The diversity of ${ }^{13} \mathrm{C}$ isotope discrimination in a Quercus robur full-sib family is associated with differences in intrinsic water use efficiency, transpiration efficiency and stomatal conductance. J Exp Bot 60:2407-2418. doi:10.1093/jxb/erp100

Roussel M, Le Thiec D, Montpied P et al (2009b) Diversity of water use efficiency in a Quercus robur family: contribution of related leaf traits. Ann For Sci 66:1-10. doi:10.1051/forest/2009010

Smith G, Figueiredo E (2011) Conserving Acacia Mill, with a conserved type: What happened in Melbourne? Taxon 60:1504-1506

Sun ZJ, Livingston NJ, Guy RD, Ethier GJ (1996) Stable carbon isotopes as indicators of increased water use efficiency and productivity in white spruce (Picea glauca (Moench) Voss) seedlings. Plant Cell Environ 19:887-894. doi:10.1111/j.1365-3040.1996.tb00425.x

Takashima T, Hikosaka K, Hirose T (2004) Photosynthesis or persistence: nitrogen allocation in leaves of evergreen and deciduous Quercus species. Plant Cell Environ 27:1047-1054. doi:10.1111/j.13653040.2004.01209.x

Warren CR, Aranda I, Cano FJ (2011) Responses to water stress of gas exchange and metabolites in Eucalyptus and Acacia spp. Plant Cell Environ. doi:10.1111/j.1365-3040.2011.02357.x 